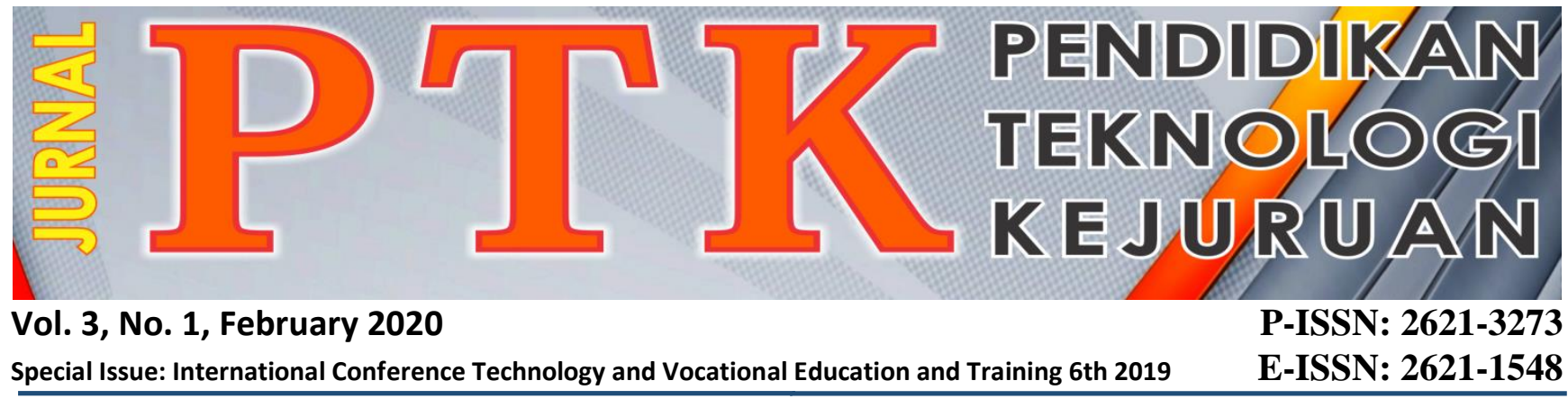

\title{
DEVELOPMENT OF COMPUTER LEARNING AND BASIC NETWORK E-MODULES
}

\author{
Satria Ami Marta, Suparno, Usmeldi, and Devri Ramdhan Apriyus \\ ${ }^{1}$ Faculty of Engineering, Universitas Negeri Padang \\ ${ }^{3}$ Chemistry Education, Universitas Negeri Padang \\ ${ }^{*}$ Corresponding author, e-mail: amimarta12@gmail.com
}

\begin{abstract}
This research is motivated by the limitations of time learning that can be used by students in the class with the characteristics of vocational learning that requires students to know with skills (competencies). The teacher-centred learning process also slows the level of mastery of the material that students should have. The purpose of this research is to produce the appropriate e-modules used in the subjects of computer and basic network students in grade $X$ TKJ at SMK. The type of this research was Research and Development by using ADDIE development model. This type of development research is with analysis (analysis) needs to be developed, design to choose Media, design and make media, development (development) test Practicality, practical done by 1 teacher and 30 students, implementation is done implementation in students by teacher, and Evaluation (evaluation) of data assessment result of multimedia-based learning module deserves to be used in Classroom as a simulation tool learning computer lessons and basic networks. Multimedia-based learning modules are applied because they are quality, easy to use and have a fascination if used in the learning process.
\end{abstract}

Keywords: ADDIE, practicality, learning module

Copyright $\odot 2020$ JPTK. All rights reserved

\section{INTRODUCTION}

The development of technology is rapidly increasing and cannot be dammed. Technological developments are also influential in the world of education. The use of technology for media in learning has evolved and the learning activities based on information and communication technology (ICT) allows educators to innovate to make better learning Media. In addition, students also use ICT to facilitate learning [1]. ICT is a technology device that facilitates its users with a wide range of ease in accessing the information needed, whether the information presented in the form of audio, text, visuals, or in the form of information symbols or emblems.

The development of information media today began to experience the transition from print media to digital media. This has an impact on the educational world, especially in terms of the presentation of teaching materials. The presentation of teaching materials is not only limited to print media limit but already utilize digital media. One form of presentation is an E-book. An electronic book or e-book is an electronic version of a printed book, read using an electronic device and a special opening software. The development of e-book technology encourages innovation in developing teaching material in learning activities. One of the teaching materials that can be transformed into an electronic form is a module. Electronic modules can be defined as an electronically designed learning tool, containing systematic and compelling material to achieve the expected competencies. The electronic module essentially in its writing structure adapts to the format, characteristics, and parts of the printed module in general.

The lack of use of learning support media is one of the problems experienced by the school today. The problem is seen from various aspects, ranging from teacher readiness, school readiness and student readiness as a learning object. Besides, there are various educational problems related to the use of media in learning such as less availability of learning support media are conducive to use in enhancing students ' enthusiasm in learning. 
The next problem found was the lack of enthusiastic learning that students had, because of the way that the monotonous material is being performed by the classroom educators. This makes students not enthusiastic about the learning process. The learning that most teachers make use of PowerPoint media as a learning tool because there is no variation in the use of media that used to make students enthusiastic to below. The main problem in the school is the limited learning media that is used for the learning process so that the learning process is not carried out optimally.

Based on the problems that have been submitted, it is needed a learning support media that can improve the student's creativity, interest, and curiosity about the teaching materials provided by the teacher, the learning process can be is carried out to the fullest and there is increased student learning. It takes a solution to increase the learning outcomes of computer and basic network students of Grade X TKJ in SMKN 4 Payakumbuh. E-modules are one of the options that can be used for computer subjects and basic network, where the E-module to be developed is designed as best as possible by prioritizing user-friendly, where students can interact with the E-module The. Aim to have the learners have a high enthusiasm when following the learning. E-module is a modification of conventional modules by combining the utilization of information technology so that the module is more interesting and interactive. Because e-modules can add multimedia facilities (images, animations, audio, and video) in them. In e-modules can also be added a test facility or an interactive evaluation so that students are more able to interact with their learning resources.

E-module is very important to develop because, through the e-module, teachers can increase the interest of learning and enthusiasm that the students have. The reason for choosing to develop e-modules compared to other media as a solution to the problem is because the utilization of e-modules is expected to be able to lure the curiosity of students to learn. With the expanding E-module, it is expected to improve student learning outcomes.

\section{METHODOLOGY}

This method of research using the type of research and development (research and Development) is the steps to develop an existing product, which can be accountable to produce educational products in the form of media, Material, tool evaluation, and so on are used as an educational troubleshooter. The R\&D research can also be interpreted by research and development methods that are utilized to create specific products and carry out the effectiveness testing of the products created. The research was aimed at developing the e-modules of the computer and the basic network through systematic measures to then be tested for its behaviour. The development Model in this study was ADDIE [6] [8] [10].

\section{A. Phase Analysis}

The purpose of the analysis is to interpret the research in detail, this step is carried out through the analysis of various matters relating to the development of modules, among others:

1. Need analysis

2. Analysis of needs is done by doing direct observation to the students as the object of research. It is then analyzed anything that is still lacking from previous e-modules and how the development is needed for the success of the teaching and learning process

3. Student Characteristics Analysis

The student's characteristic analysis is carried out by identifying the characteristics of participants who will utilize the E-module learning according to the observation and talks with the teacher of computer subjects and basic network of the class, that students prefer guidance in learning, and love the variety of exercises the teacher has presented. Through the student's character analysis, researchers can determine which techniques are appropriate to use for learning.

\section{B. Planning Phase}

The design phase begins with determining the main concepts in the subjects of the computer and basic network and designing and drafting them into a valid, practical and effective e-module of learning.

\section{Development stage}

At this stage, creating improved learning modules based on the suggestions and feedback from some of the experts gained from the trial. This learning Emodule is corrected according to the validator's suggestion. This stage aims to produce a valid, practical and effective e-module of learning.

\section{Implementation phase}

The implementation phase is interpreted as the realization stage of the planning and development phases. The implementation stage means the implementation of matters relating to the development of e-module learning that is to test the Learning e-module on the learning of computer and basic network in SMK. Implementation of the Learning E-module is done after completion of the validation stage. 
E. Evaluation Stage

The evaluation phase is the basis for the action to take actions on the treatment of a tested learning emodule. Action taken in the improvement of the Emodule learning made, including:

1. Implementing final revisions after the E-module learning is developed applied to the learning process of computer and basic network.

2. Generate suitable learning support media utilized on teaching computer and basic network in SMK

\section{RESULT AND DISCUSSION}

Research results through observation sheets of multimedia-based learning modules from teachers and students. The assessment will get responses or opinions from teachers and students to determine the practicality of the module. Practical measurements using a Likert scale consisting of 4 alternatives are 4 (very good), 3 (Good), 2 (not good) and 1 (very unwell). Provision of practical value with the formula:

Value of practicality in $\%=\frac{\text { Total Practical value }}{\text { Maximum practicality value }} \times 100$

A. Result

1. Teacher response to multimedia-based learning practices module.

Practicality is associated with the convenience of using multimedia-based learning modules developed. Practical Data is obtained through a poll which is filled by teacher teachers simulation lessons and digital communication. Assessment results for exercise are summarized in the table.

Table 1. The Aspects of Assessment

\begin{tabular}{clll}
\hline No & \multicolumn{1}{c}{$\begin{array}{c}\text { Aspect } \\
\text { Assessment }\end{array}$} & Percentage & $\begin{array}{c}\text { Teacher } \\
\text { Value } \\
\text { Category }\end{array}$ \\
\hline 1 & $\begin{array}{l}\text { Quality Media } \\
\text { Content }\end{array}$ & $\mathbf{9 8 , 5 7 \%}$ & Very practical \\
2 & $\begin{array}{l}\text { Convenient } \\
\text { Module Usage }\end{array}$ & $\mathbf{9 2 , 5 \%}$ & Very practical \\
3 & $\begin{array}{l}\text { Interesting } \\
4\end{array}$ & $\mathbf{9 7 , 5 \%}$ & Very practical \\
Efficiency & $\mathbf{9 0 \%}$ & Very practical \\
\hline
\end{tabular}

Average practical teacher response 100\% Very practical. From the table analyzed the practicality test results of multimedia learning module by the teacher is $100 \%$ so that the module can be concluded in the category "Practical".

2. Student response to a practicality-based multimedia learning module.

The practicality module also requires input in the form of a student's response. This Data is obtained after the students use a multimedia-based learning module, then the student fills with the given poll. The assessment result for practicality based module learning is summarized in the table.

Table 2. Rating Aspects

\begin{tabular}{|l|l|c|c|}
\hline No & \multicolumn{1}{|c|}{$\begin{array}{c}\text { Rating } \\
\text { Aspect }\end{array}$} & Percentage & Category \\
\hline 1 & $\begin{array}{l}\text { Quality Media } \\
\text { Content }\end{array}$ & $85.90 \%$ & Very practical \\
\hline 2 & $\begin{array}{l}\text { Convenient } \\
\text { Module } \\
\text { Usage }\end{array}$ & $88.50 \%$ & Very practical \\
\hline 3 & Interesting & $86.50 \%$ & Very practical \\
\hline 4 & Efficiency & $87.00 \%$ & Very practical \\
\hline
\end{tabular}

Average student practical response $86.98 \%$ Very practical. Based on the teacher response and student response tables, the average result of the Multimedia learning module is based on the practicality according to the teacher $100 \%$ and corresponds to the students at $86.98 \%$, so that the learning module can be concluded multimedia-based Included in category "very practical.

\section{B. Discussion}

Various research results say that the use of multimedia is very good for use during the learning process and should be done in the discipline of science as it can contribute to improving learning and understanding Learners in the process of thinking and reducing deficiencies naturally in the learning process [1] [4]. One of the results showed that the web-based e-modules on static electrical and dynamic electrical materials could be utilized as learning support media [11].

The same statement reveals that the use of multimedia in building learning the competence of vocational students [3]. Analysis Module learning is developed as a core component in shaping a centralized environment of learning on students to improve quality in students [5]. In other words, multimedia is very good to use in the learning process because it meets the criteria of practicality and increases learning ability and creativity of children actively.

\section{CONCLUSION}

Based on the results of the research module development of multimedia-based learning simulation and digital communication that has been done, then obtained the conclusion of development research examined by the ADDIE model produces a module Multimedia-based learning of simulated subjects and digital communication to suit the needs of learners. Multimedia-based learning module presented with the competency material format that 
students must achieve, equipped with learning objectives and time, a summary of learning materials, and training questions to measure student learning outcomes. A multimedia-based learning module that helps learners to receive learning in the classroom according to the learning Times. A multimedia-based learning module that learners can use anytime and anywhere when learners want to revisit learning (self-learning).

\section{REFERENCES}

[1] Beydogan, HO \& Hayren Z. The Effect of Multimedia-Based Learning on the Concept of Students' Levels and Learning Attitudes. Journal of Eurasian Education Research, Edition 60, 2015, 261-280. 2015.

[2] [2] Hake. Analyzing Change /Gain Scores. 1999.

[3] Hamonangan, Tambunan \& Efendi, Napitupulu. Interactive Effectiveness of Multimedia-Based Learning Models in Engineering Mechanics. International Education Studies; Vol.9, No.10; 2016 ISSN 1913-9020 E-ISSN 1913-9039 Published by the Canadian Center for Science and Education. 2016.

[4] Leow,Ms. Fui-Theng. Interactive Multimedia Learning: Educational Innovation Classes at the University of Malaysia. TOJET: Turkish Online Education Journal of Technology April 2014, volume 13 edition 2. 2014.

[5] Muhammad, Rusli. Effects of Animation in Multimedia Computer Based Learning and Learning Styles on Learning Outcomes. Turkish Online Journal of Distance Education-TOJDE October 2017 ISSN 13026488 Volume: 18 Number: 4 Article 13. 2017.

[6] Nana, Sudjana. Learning outcomes Assessment. Jakarta: Rajawali Press. 2005.

[7] Riduwan. Variable-Variable measurement scale. Bandung. Alfabeta. 2010.

[8] Robert maribe branch. intrucional design: the addie approach. 2009.

[9] Smaldino, S E., Deborah L. Lowther ., James D. Rusel. Instructional Tecnology \& Media. for

Learning: Technology Learning and Media for Learning . Translator . Arif Rahman . Eds. Ni nth . Jakarta: Kencana. 2011.

[10] Sugiyono.Quantitative, Qualitative, and $R \&$ $D$ Research Methods . Bandung: Alfabeta. 2012.
[11] Taufik Solihudin Development of E-WEBbased modules to improve the achievement of physics knowledge competency in static and dynamic SMA material. Journal of Vehicle Physics Education, 3 (2), 51-61. 2018.

[12] S. Syahril, N. Jalinus, R. A. Nabawi, and Y. Arbi, "The Create Skills of Vocational Students to Design a Product: Comparison Project Based Learning Versus Cooperative Learning-Project Based Learning," Adv. Soc. Sci. Educ. Humanit. Res., vol. 299, no. 5th UPI International Conference on Technical and Vocational Education and Training (ICTVET 2018) The, pp. 316-320, 2019. 